\title{
DIABOS ENCARNADOS \\ CARNAVAL E LIBERDADE \\ NAS RUAS DO RIO DE JANEIRO (1879-1888)
}

Eric Brasil Nepomuceno (UFF)

Este artigo busca entender os caminhos e escolhas da população de cor para alcançar espaços de autonomia e participação no carnaval e na sociedade, partindo dos carnavais cariocas da década de 1880; aborda também as construções de jornalistas e autoridades públicas sobre o tema. Para tanto toma como objeto de estudo uma fantasia carnavalesca que na última década de vigência da escravidão no Brasil se destacou nas ruas da cidade do Rio de Janeiro: a fantasia de diabinho. Os sujeitos que usavam essa fantasia contribuíram para as discussões acerca dos limites da cidadania e da liberdade nas ruas da cidade às vésperas da abolição da escravidão.

RIO DE JANEIRO; CARNAVAL; ABOLIÇÃO; DIABINHOS.

NEPOMUCENO, Eric Brasil. Diabos encarnados: carnaval e liberdade nas ruas do Rio de Janeiro (1879-1888). Textos escolhidos de cultura e arte populares, Rio de Janeiro, v.10, n.2, p. 7-28, nov. 2013. 


\section{EMBODIED DEVILS}

CARNIVAL AND FREEDOM

IN THE STREETS OF RIO DE JANEIRO (1879-1888)

Eric Brasil Nepomuceno (UFF)

This article aims at understanding the ways and choices made by people of color to reach spaces of autonomy and participation in carnival and society, starting at the carnivals of Rio in 1880s; the article also addresses the construction by journalists and public authorities on the subject. For this, it takes as its object of study a carnival costume that, in the last decade of existence of slavery in Brazil, stood out in the streets of Rio de Janeiro: the little devil costume. The subjects who wore this costume contributed to the discussions on the boundaries of citizenship and freedom in the streets of the city on the eve of the abolition of slavery.

CARNIVAL; RIO DE JANEIRO; SLAVERY ABOLITION; LITTLE DEVILS.

NEPOMUCENO, Eric Brasil. Diabos encarnados: carnaval e liberdade nas ruas do Rio de Janeiro (1879-1888). Textos escolhidos de cultura e arte populares, Rio de Janeiro, v.10, n.2, p. 7-28, nov. 2013. 


\section{INTRODUÇÃO ${ }^{1}$}

Calixto José da Silva trabalhava como cocheiro. Circular pelas ruas das freguesias centrais do Rio era uma obrigação de sua labuta diária. Havia algumas semanas devia reparar na mudança significativa pela qual as principais ruas estavam passando. A Rua da Quitanda já era enfeitada pelos moradores e comerciantes. Na Rua do Ouvidor as casas "afrancesadas" penduravam bisnagas e seringas em suas portas. A comissão de festejos da Rua Gonçalves Dias levantava um coreto para banda de música. Na Casa do Vaz, loja de número 14 da Rua da Constituição, moleques compravam cera para que suas patroas fizessem os famigerados limões de cheiro. Os preparativos anunciavam a iminência do Carnaval de 1883.

Ao retornar a sua moradia, na Rua da Princesa, freguesia de Santana, Calixto planejava os passos da próxima semana. Sua fantasia já estava pronta: maillot encarnado, com guizos nas mangas e nas bainhas da calça, cauda de algodão (comprida o suficiente para ser enrolada à cintura), máscara de nariz e boca protuberantes e chifres tão característicos. Naquele ano sairia de diabinho pelas ruas do Rio.

A alguns quarteirões dali, na Rua da Prainha, mais um diabinho se preparava. Domingos Ramos, carpinteiro, de 19 anos, vestiu a roupa vermelha e reparou que ficou bastante justa em seu corpo, consequência do seu metro e 71 centímetros de altura.

Saíram e infernizaram as ruas da freguesia de Santana, como era de esperar por sua indumentária. Pularam, gritaram, caluniaram e ofenderam os demais foliões com suas pilhérias: "Oh! Oh! Você me conhece?"

Segundo a Gazeta de Notícias de 8 de fevereiro de 1883, quinta-feira, Calixto José da Silva e Domingos Ramos foram presos por "andarem fazendo distúrbios pelas ruas do $2^{\circ}$ distrito de Santana", juntamente com mais sete diabinhos: João Paulo Fernandes, Luiz Ezequiel Pinheiro, Francisco Alves de Souza, José Pereira Garcia, Sancho, escravo de João José de Azevedo Costa, Orlando, escravo do doutor Hermogeneo Pereira da Silva e Alfredo de Tal.

O carnaval não acabou bem para eles: na terça-feira gorda, 6 de fevereiro de1883, Calixto e Domingos entraram na Casa de Detenção da Corte juntamente com outros 91 sujeitos trajando "roupa à fantasia". A ficha de Calixto José da Silva nos revela que ele tinha 24 anos, 1,68m, era solteiro; natural de Campo Grande, trabalhava como cocheiro e morava na rua da Princesa. Sua cor era fula. ${ }^{2}$

A ficha de Domingos Ramos traz as seguintes informações: tinha 19 anos e $1,71 \mathrm{~m}$; era fluminense e carpinteiro, e morava na rua da Prainha. Sua cor era pre- 
ta. João Paulo Fernandes aparece no livro da Casa de Detenção como fluminense de 17 anos, pedreiro. Sua cor era parda. ${ }^{3}$

O grupo apresentado pelo jornal contava ainda com dois escravos, Sancho e Orlando. Também fantasiados de diabinho, eles participavam da festa lado a lado com homens livres.

Neste artigo nos aproximaremos destas figuras tão presentes nos relatos desses antigos carnavais: os diabinhos. Qual a imagem que intelectuais, jornalistas e autoridades policiais faziam desses foliões endiabrados? E por que, apesar de existirem tantas outras fantasias e de brancos e morenos também se fantasiarem de diabos e diabinhos, essa fantasia foi tão acionada pelos foliões negros e mestiços? Quais as experiências dos diabinhos nas ruas do Rio às vésperas da abolição? Essas questões pautam as páginas que se seguem e nos ajudaram a entender as escolhas dessa população durante os embates em torno dos novos significados da liberdade e da cidadania na iminência da abolição.

\section{CLASSES PERIGOSAS E DIABÓLICAS}

Segundo os dicionários coevos e os relatos de memorialistas e folcloristas, a imagem do diabinho festivo no Brasil era do jovem homem esperto, vivo, sabido, travesso, caluniador, autor de obras terríveis e maravilhosas. ${ }^{4}$ Sua figura contribuiu para os rumos do carnaval carioca, posto que foi utilizada tanto por autoridades e jornalistas - como inimigo e alvo a perseguir - quanto por negros livres e escravos - como instrumento para fazer valerem seus projetos e aspirações de participação no carnaval e na sociedade que se construía.

Nas últimas décadas do século XIX, por meio das páginas dos jornais, podemos notar a multiplicação de registros de crimes envolvendo mascarados e, mais do que isso, a associação com crimes de práticas antes comuns e toleradas. Tal fato ocorre especialmente com a pilhéria, a sátira, que passa a ser tratada como crime do porte das agressões físicas (CUNHA, 2001, p.30-31).

Isso não significa, contudo como chama atenção Maria Clementina Pereira Cunha (2001), que nesse período essas práticas e crimes tenham tido aumento significativo em sua incidência, em relação às décadas anteriores. Segundo a autora,

Na verdade, a imprensa carioca passava nesse período por uma transformação muito intensa em direção à massificação e à busca de um público leitor mais amplo e indiferenciado. Por isso, o interesse em noticiar ocorrências capazes de atrair a curiosidade de muita gente pode ter gerado o aumento desses registros nas colu- 
nas de jornais, ampliando o seu significado e alcance em busca do interesse dos leitores.

Isso, consequentemente, acabou reforçando uma imagem de perigo em torno de certas práticas e fantasias carnavalescas. Com isso, "os mascarados que frequentavam as ruas desde séculos atrás, associados às ocasiões festivas, apareciam então colados à noção de crime e de violência" (p.31). São os diabinhos o principal foco desse olhar temeroso na década final do regime escravista.

A construção dessa imagem de perigo em torno dos diabinhos, contudo, não é despretensiosa e ocasional. Os relatos dos jornais que ajudam a engendrar esses estereótipos, se não refletem apenas um possível aumento do número de troças e diabruras, também não são apenas reflexos de uma estratégia mercadológica para aumentar o público consumidor. Essa estratégia está diretamente ligada à desestruturação da escravidão, à redefinição das relações sociais e aos limites da participação e cidadania que vinham sendo veiculados com o avançar dos debates abolicionistas.

Como bem mostra Célia Marinho Azevedo (1987), a onda negra que se espalhava pelo país gerava temor crescente no imaginário das elites. $E$, ao passo que os movimentos pela abolição e transformação das formas tradicionais de controle social se tornavam bandeiras cada vez mais populares, essas elites buscavam caminhos para manter a ordem, nela incluídos alguns representantes de segmentos dos movimentos abolicionistas (MACHADO, 1994).

Na capital do Império do Brasil, na década de 1880, a insistência de indivíduos negros, livres ou escravos, em sair no carnaval num anonimato diabólico - na feliz expressão de Maria Clementina Cunha - está diretamente relacionada a práticas históricas da população de $\operatorname{cor}^{5}$ na cidade de tentar ocultar sua condição civil. Pois, "era no corpo do escravo que se gravava sua condição - e a cor da pele funcionava como um claro critério de diferenciação social -, razão pela qual as formas de controle social passavam pelo reconhecimento pessoal e pela exibição de características raciais" (CUNHA, 2001, p. 39-40).

Apesar de inúmeras outras fantasias propiciarem a dissimulação da condição social e racial do folião, pretendo demonstrar que a fantasia de diabinho foi eleita por muitos jovens negros e mestiços como caminho de atuação criativa na festa carnavalesca. Trazia consigo possibilidades de afirmação social perante seus pares, expressão de valores e autorrepresentação perante a sociedade como um todo.

Portanto, ocultando a identidade e, consequentemente, ameaçando a hierarquia social, o diabinho foi um dos principais representante das "classes 


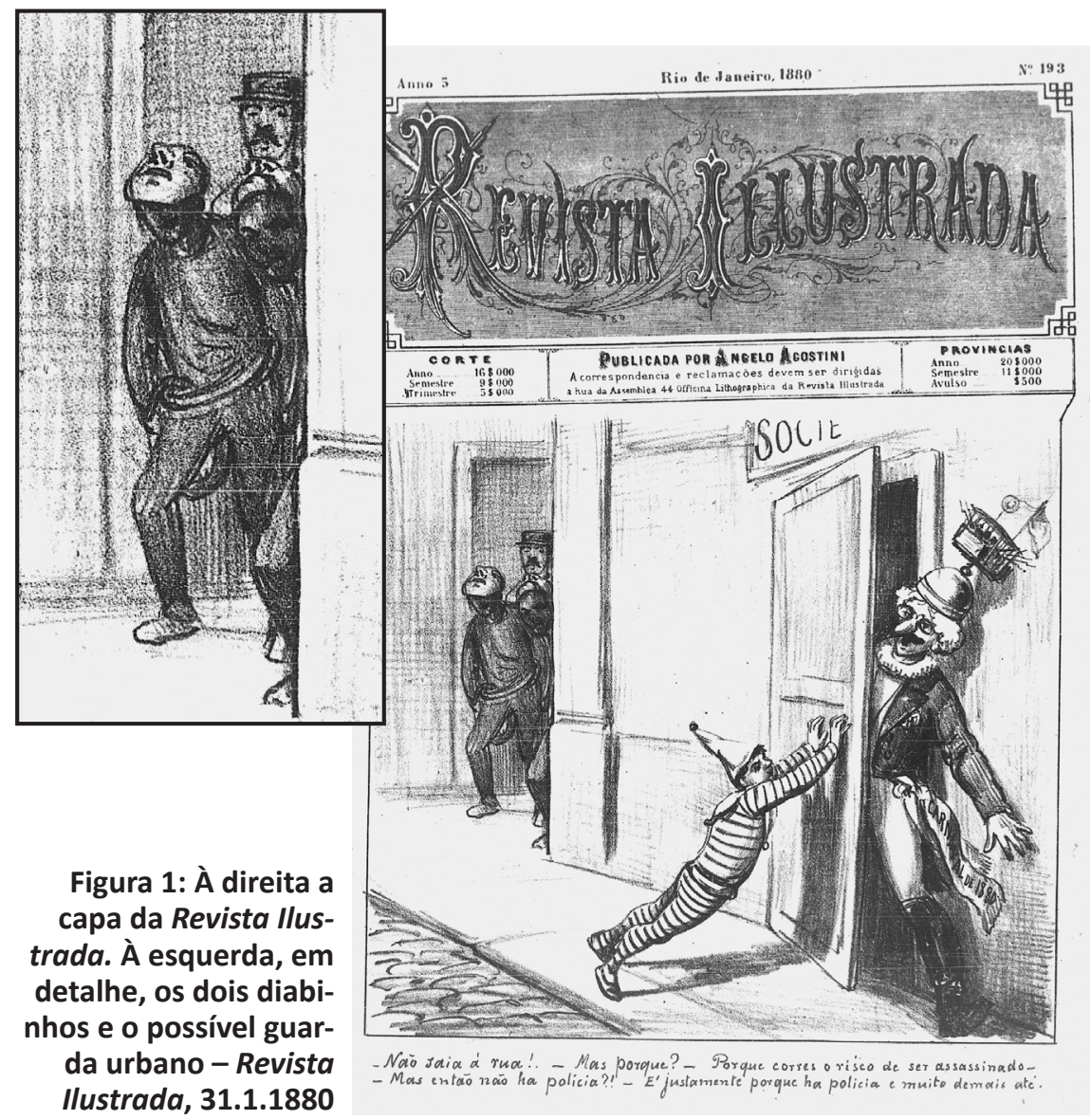

perigosas $^{\prime 6}$ no carnaval do Rio de Janeiro, sob a perspectiva das autoridades e de jornalistas.

Na capa da Revista llustrada de 31 de janeiro de 1880 (Figura 1), o pequeno repórter que simbolizava o periódico de Angelo Agostini tentava impedir que um fantasiado representando o Carnaval de 1880 saísse às ruas. À espreita, numa esquina escura, observam dois diabinhos e um possível guarda urbano.

O diálogo entre esses dois personagens é revelador. O pequeno repórter, experimentado nas ruas do Rio, alerta o "inocente" Carnaval dos perigos de sair daquela porta para fora. O pequenino o alerta que, uma vez nas ruas, ele poderá ser assassinado. A surpresa do Carnaval de 1880 se reflete em sua pergunta: “Mas então não há polícia?". E a resposta é desconcertante: “É justamente porque há polícia e muita demais até".

Os assassinos em potencial do Carnaval de 1880 são dois diabinhos de rosto indistinguível na escuridão, aliados a um indivíduo que se assemelha a um 
guarda urbano. A reclamação de Angelo Agostini ataca a autoridade policial duas vezes: primeiro ao destacar sua incompetência em garantir a segurança da festa "civilizada", o direito à liberdade de sair às ruas para brincar o carnaval. ${ }^{7}$ Por outro lado, faz clara associação entre os diabinhos e a violência e entre estes e a força policial da Corte.

Essa imagem de perigo e ameaça colada aos diabinhos aparece nos jornais aliada a uma postura de desdém e desprezo. É recorrente a afirmativa cheia de insatisfação dos jornalistas de que já não há mais carnaval ou máscaras avulsos, sobram apenas os diabinhos encarnados, um ou outro dominó e raros velhos de cabeças grandes.

Os diabinhos estarão constantemente ligados a adjetivos como sensaborões, tolos, desenxabidos, etc., quando não estão atrelados a referências de violência e desordens. Não parece haver dúvida para esses jornalistas de que eram os diabinhos os principais representantes da festa atrasada e perigosa, que só tinham um destino óbvio: o xadrez.

Contaram-se por centenas os conhecidos diabinhos.

Andaram eles por toda parte, isolados ou em grupos, cheios de convicção sincera de que eram muitíssimo divertidos, e bendizendo, como excelentemente empregados, os $2 \$ 500$ com que adquiriram tão elegante vestuário, com máscara e tudo.

Foram eles, os diabinhos, os principais fregueses das diligencias que circularam a galope esta heroica cidade de S. Sebastião(GAZETA DE NOTÍCIAS, 8.3.1886).

A ironia empregada na notícia é evidente. Para o jornalista não eram nem engraçados nem elegantes. Os dois mil e quinhentos réis, valor da fantasia completa de diabinho, não chegava nem próximo do valor de dominós de cetim, mefistófeles, reis da França e Chicards, que podiam custar dez vezes mais (25\$000!). O que para os diabinhos seria divertido e belo correspondia ao perigo e ao crime para o jornalista, o que os tornava os "fregueses" preferenciais das diligências policiais dos dias de carnaval.

A suposta vitória em quantidade dos dominós sobre os diabinhos no Carnaval de 1886 é descrita com esperança e ceticismo nos jornais.

Uma infinidade de máscaras a pé percorreram ontem as ruas. $\mathrm{E}$ há um fato que precisa ser considerado: os dominós suplantaram os diabinhos. Querem alguns que isto seja fenômeno progressista, tão progressista como a derrota dos limões de cheiro pelas hostes compactas das bisnagas (GAZETA DE NOTícIAS, 10.3.1886). 
Derrotar os diabinhos representava o progresso, já que tais fantasias eram atreladas ao crime e a formas arcaicas de diversão, como os tão combatidos limões de cheiro. A esperança na derrota dos diabinhos, logo quando da radicalização do processo abolicionista, esbarra na realidade. Os jornalistas fazem essa estimativa durante o dia, e muito provavelmente do alto da sacada da redação do seu jornal, nesse caso, na Rua do Ouvidor. Contudo, apesar de a Rua do Ouvidor ser o centro mais atraente dessa festa, os arrabaldes também fervilhavam nos dias de Momo, e a farra varava a noite, muitas vezes esquentando apenas depois de as redações dos jornais fecharem suas portas.

Os princezes e diabinhos não deixaram de comparecer, não só nas ruas da cidade, como também nos arrabaldes atroando os ouvidos do burguês pacato e sério com os seus oh! ohs! em cabriolas endiabradas e o: - Você me conhece desenxabido e costumeiro (GAZETA DE NOTÍCIAS, 8.3.1886).

Duas crônicas publicadas no mesmo dia, 21 de fevereiro de 1887, uma na Gazeta de Notícias e outra na Gazeta da Tarde, elegeram como personagem principal o diabinho. Ambas, com grandes doses de ironia, versam sobre um dia de carnaval na vida desse "demônio". José Telha, pseudônimo de Ferreira de Araújo (fundador da Gazeta de Notícias), em sua coluna "Macaquinhos no Sótão", diz ter visto no domingo às seis horas da manhã, passar pela sua janela um diabinho encarnado, "de sapatos enfeitados de guizos, porta-voz, e a máscara deitada na cabeça a olhar para quem está à janela, enquanto o mascarado olha para quem Ihe vai adiante." Seu texto levanta pistas tanto da forma de atuação desse fantasiado na festa quanto das projeções do jornalista sobre seu destino. Prossegue José Telha:

Deve ter acordado cedo, se é que dormiu, se é que não andou toda a noite a bailar pela cabeça a ideia do figurão, que ia fazer no dia seguinte, e do muito que ia divertir-se, a palmilhar esta cidade inteira, ao sol e à chuva - às chuvas de toda ordem -, gritando, pulando, dançando, ora a rufar num tambor, ora a empunhar um archote, a envolver-se aqui num rolo, a incorporar-se ali num grupo, arriscando a encontrar uma alma caridosa, que o convide a matar o bicho, ou algum capoeira que Ihe ponha as tripas ao sol(...)

Alguns dormem nas estações da polícia, outros vão dormir à Misericórdia, e já um amanheceu na mesa de pedra do necrotério.

As opções elencadas pelo colunista não são muito otimistas: tripas ao sol por um capoeira; dormir na estação policial; ir ao hospital da Misericórdia ferido; ou mesmo amanhecer no necrotério da cidade. O destino do diabinho estaria inevitavelmente atrelado à violência, a crimes e à morte. Mas também pode- 
mos reconhecer no texto elementos da atuação desse mascarado. "Palmilhava" a cidade inteira, movendo-se com desenvoltura entre grupos variados (com archote, tambores, envolvidos em tumultos). Apresentava dessa forma um caráter de liberdade de trânsito em diferentes espaços e reforçava sua individualidade.

O texto da Gazeta da Tarde, se não fala em amanhecer no necrotério, apresenta um diabinho tolo e insípido, que também está envolvido em desordem e violências. O diabinho seria o rei dos "princezes", e no carnaval sua liberdade seria incontestável, e estaria protegido até pela polícia, incapaz de impedi-lo:"Nestes três dias a polícia não me mandará arrancar o carão, ela é minha amante, nós somos camaradas, o chefe que me serve terá carícias para o meu esperneamento, sorrisos para as minhas vergonhas."

Ele é o "tolo" que faz os demais rirem, anda alienado atrás de qualquer turba, barulho, música que aparecer. Mas também é aquele que vocifera até enrouquecer, explicitando que a fala era tão importante quanto a dança e as piruetas.

Eu sou assim, concentro-me numa frialidade conveniente; isolo-me numa neutralidade que faz bem à barriga; atiro-me para onde me chama a turba dos meus iguais e ali, loucamente sem outra razão a não ser a tolice característica dos diabinhos, vocifero e enrouqueço a alinhavar nas coisas de que muitos riem-se, sem que as entenda, e a que a maior parte despreza com o erguer de ombro dos honestos.

Mas dessa inocente futilidade, o diabinho encerra sua "gazeta" alardeando sua força assustadora: o anonimato e a navalha.

Não penseis, porém, que tão cedo deixei de ser o patrão dos princezes. Correrei com eles por praças e becos, navalhando com a mentira, acrobateando de um lado para outro, já no meio de cadáveres políticos que eu penso, vive já entre os secretas meus amigos, ora com carão dos três dias de Momo, ora com a caraça que me é própria, sempre todos me ignorando e rejeitando.

Tanto com o carão dos dias de Momo quanto com a "caraça que lhe é própria" nos dias restantes do ano, o diabinho é rejeitado e ignorado, até o momento em que surge, violento e "incivilizado". O diabinho, segundo essa fonte, é o desqualificado dessa sociedade não apenas no carnaval, mas também nos dias restante do ano.

Essas duas crônicas abrem a possibilidade de interpretação mais próxima da imagem desses foliões para jornalistas representantes das folhas diárias mais importantes do Rio de Janeiro: seriam fantasias capazes de mascarar a violência 
desses sujeitos; representam o perigo para o "burguês pacato" que pretende sair às ruas e apreciar o carnaval.

Entretanto, ambos os textos também favorecem nossa aproximação com as práticas desses sujeitos sociais que escolhiam fantasiar-se de diabinho: em geral agiam individualmente na festa, circulando por diversos espaços e grupos carnavalescos, desfilando com archotes, tocando tambores, participando de grupos mais organizados; o canto, a pilhéria, a dança e as piruetas fazem parte de suas características, o que é reforçado por suas máscaras com grandes línguas e por sua fama de dançarino e capoeira (Figura 2).

Mas nem só de brincadeiras pacíficas se constitui a prática dos diabinhos: a violência e a virilidade estão recorrentemente presentes nas fontes que os envolvem. São homens jovens, muitos capoeiras, que têm como elemento formador de sua identidade a capacidade e habilidades nos chutes, cabeçadas, navaIhadas e no uso de cacetes (tanto como arma quanto como adereço festivo).

A capoeiragem aparece como importante elemento para entendermos mais profundamente a ação desses foliões e mesmo sua imagem frente a autoridades e jornalistas do período.

\section{DIABOS, CAPOEIRAS FANTASIADOS?}

Quando o estadunidense C. Andrews esteve no Brasil, ele assistiu a vários carnavais. Sua percepção foi que na década de 1880 a festa perdia a popularidade, pois as classes mais altas do Rio permaneciam em casa nos três dias de Momo. Provavelmente seu círculo social no Rio lhe deu essa impressão. Contudo, ele não deixou de notar um fato, que lhe chamou a atenção.

Segundo Andrews (1887), o evento que primeiro desperta as pessoas para a proximidade do "festival" é o aparecimento de jovens vestindo roupas vermeIhas apertadas, chifres e longos rabos. São chamados de diabos e frequentemente usam máscaras. Vindo de um país em que as relações raciais acontecem de forma muito diversa da brasileira, o americano não relega às entrelinhas a cor desses indivíduos: esses jovens seriam especialmente negros e mulatos (p. 41). Não estava acostumado com a política de dissimulação racial brasileira...

A cor dos indivíduos nas páginas dos jornais aparece apenas em ocasiões específicas. Quando tratam genericamente dos préstitos das grandes sociedades ou escrevem editais atacando o entrudo, as cores dos indivíduos não aparecem com frequência. Nessa situação as abordagens são muito mais abstratas e versam sobre o Zé-Povinho "sem educação" que "ameaça" as práticas civilizadas dos préstitos, dos bons rapazes e famílias respeitáveis. 


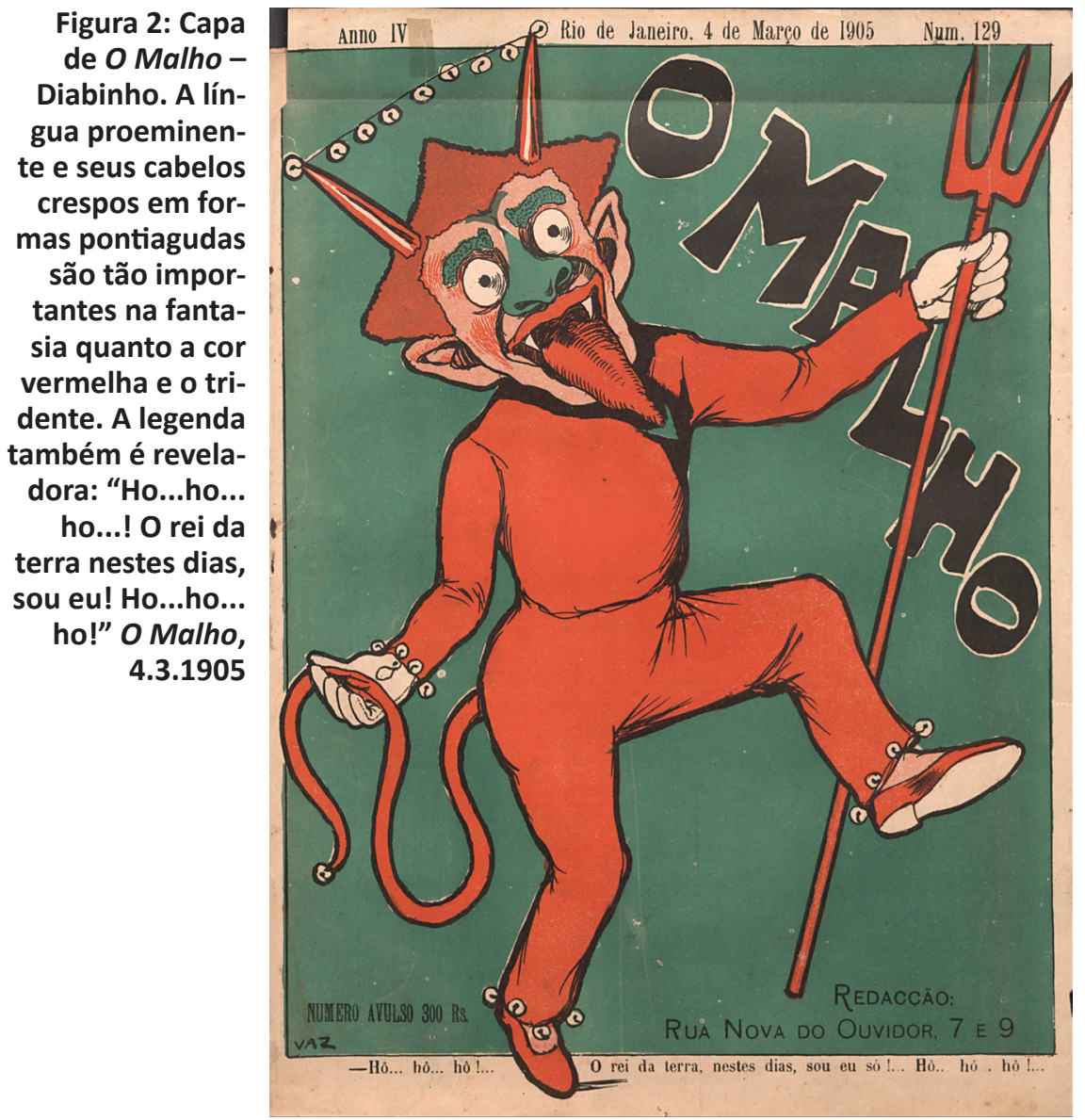

Quando, entretanto, passamos às páginas de notícias policiais, o quadro é outro. As poucas referências à cor dos indivíduos aparece aí. Podemos notar que a regra é o silenciamento da cor, o que não quer dizer que nessa sociedade inexista o preconceito racial. O que importa ressaltar, contudo, é quando a cor dos sujeitos é explicitada: nos momentos de conflitos, crimes e atos de violência, o que é bastante relevante para entendermos as relações sociais e raciais no período.

Apesar da crescente racialização da escravidão no século XIX, ela não serviu no Brasil para justificar a condição de escravo abertamente. Segundo Hebe Mattos (2004), a ideia de raça era por demais explosiva no Brasil para servir a tal fim, principalmente em função do grande número de negros livres e mestiços. Legalmente a justificativa da escravidão se fez através do arcabouço liberal, pelo direito à propriedade. 
E a própria população livre de cor reivindicava a igualdade com os demais cidadãos livres, silenciando a própria cor em muitos momentos, pois esta permanecia como marca de discriminação mesmo após a conquista da liberdade. "Uma reivindicação de silenciamento que se fazia, entretanto, de forma politizada e muitas vezes ameaçadora" (MATTOS, 2004, p. 22).

O temor de racializar a inferioridade ou a violência parece ter feito com que os jornalistas evitassem ao máximo colorir suas notícias, fazendo apenas em casos isolados. Mas nem por isso devemos deixar de perceber que os termos preto, pardo, negro, crioulo e mulato aparecem em esmagadora maioria em relatos de violência e crimes, sem que nenhuma vez apareça outras cores, como branca, por exemplo.

A constância desses termos e sua relação ou não com crimes e violência nos jornais também deve ser analisada. No Jornal do Commercio e na Gazeta de Notícias encontrei 28 vezes a ocorrência da cor (sem contar anúncios de escravos) em cada um. No Jornal do Commercio, dos 28 registros, 23 eram pretos (seis escravos), dois pardos (um escravo), um mulato e dois crioulos. Todos estavam envolvidos em algum tipo de ação violenta.

Na Gazeta de Notícias, nos 28 registros, há 13 pretos (dois escravos e um liberto), seis pardos (dois escravos), sete crioulos (um escravo), uma mulata e um negro. Além de muito maior equilíbrio na utilização dos termos, dez deles tratavam de representações de pessoas de cor em carros de ideias de Fenianos e Democráticos, fantasias de escravos e artigos sobre formas de brincadeira carnavalescas (como o artigo de Mello Moraes filho sobre os cucumbis).

O cenário apresentado pela Gazeta da Tarde é bem diferente. Esse jornal, órgão principal da imprensa ligada aos ideais abolicionistas, só utilizou referências à cor em seis ocasiões, em nenhuma delas mencionando escravos, em duas, pretos, em uma, pardo e em três, negros. Apenas uma tratava de agressão física, outra era sobre um preto que se dizia livre e que foi encontrado ferido, e as demais eram sobre carros de ideias das grandes sociedades carnavalescas.

As diferenças entre os três jornais é significativa. O Jornal do Commercio, o mais conservador dos três, muito mais alinhado a posições escravistas, possui muito menos nuanças ao usar os termos preto, pardo e crioulo, e só os utiliza quando trata de crimes. A Gazeta de Notícias, primeiro grande jornal da Corte a defender o abolicionismo, mas sem posturas radicais, já apresenta mais sutileza e variações na utilização desses termos. Também os utiliza em situações diversificadas e não apenas de violência, sobretudo quando se refere a ações abolicionistas das sociedades carnavalescas. A posição da Gazeta da Tarde é ainda mais interessante. Esse jornal, por sua pública filiação abolicionista, evita ao 
máximo utilizar expressões racializadas. Utiliza um termo que não está presente no vocabulário dos demais (aparecendo na Gazeta de Notícias apenas no texto de Mello Moraes): negro. Usa a palavra negro para se referir àqueles sujeitos de cor que participavam dos carros de ideias das grandes sociedades carnavalescas, geralmente ganhando cartas de alforria.

O diabo é a fantasia carnavalesca que mais aparece adjetivada com os termos pardo, crioulo, preto e escravo nos jornais analisados. Nas notícias referentes a conflitos e crimes, a única fantasia que encontrei explicitada foi a de diabinho, ou então o termo genérico "mascarado", ou a ausência de fantasia. As principais acusações são de capoeiragem, desordem, vagabundagem e ofensas físicas.

Esses diabos, para tristeza dos jornalistas, eram a manifestação carnavalesca mais popular nas ruas cariocas, sobretudo entre os escravos, libertos e negros livres pobres. Nas palavras lamuriosas da Gazeta de Notícias do domingo de carnaval de 1883, "o Zé Povinho quase só tem uma manifestação no carnaval: o diabinho encarnado"(GAZETA DE NOTícIAS, 4.2.1883).

As "ocorrências da rua" (seção da Gazeta de Notícias) publicadas na Quarta-feira de Cinzas do Carnaval de 1883 oferecem boa dimensão da imagem dos jornalistas sobre os diabinhos, mas também abrem várias outras questões: "Os diabos, isto é os capoeiras por essa forma fantasiados, continuaram anteontem a praticar diabruras". O jornalista lança mão, já na abertura de seu texto, de uma frase que sintetiza a imagem que pretende reforçar sobre os que se fantasiam de diabo durante o carnaval carioca. Segundo ele, na festa os diabos são representados majoritariamente por capoeiras. As diabruras cometidas por esses foliões são entendidas como inerentes e naturalizadas, já que não se espera de capoeiras outra atitude senão a violência.

Os diabos foram considerados a expressão máxima da ação dos capoeiras na festa. Por isso é importante entendermos um pouco melhor quem eram esses capoeiras e quais suas práticas e motivações em finais do Império do Brasil. ${ }^{8}$

Segundo Carlos Eugênio Líbano Soares (2002), as festas representaram um dos momentos de maior atuação dos capoeiras no Rio de Janeiro. Desde a primeira metade do século XIX, os dias festivos do calendário religioso, as festas cívicas nacionais eram marcadas por grande atividade das maltas de capoeiras, sobretudo, nas celebrações realizadas nos meses que marcam a virada do ano: dezembro, janeiro e fevereiro - como o Natal, o Dia de Reis e o carnaval. Era um período - como ainda hoje o é - de temperatura elevada, com dias mais longos, "que incentivava os moradores brancos e portugueses a se refugiar em casa, em longas sestas" (p. 298-299), enquanto a população de cor ocupava as ruas. 
A capoeira teve papel fundamental na atuação da população de cor na cidade do Rio e consequentemente dos padrões de repressão e das imagens incutidas e propaladas por autoridades, jornalistas, literatos, cronistas ao longo do século XIX. Segundo Soares (1993), 91\% dos indivíduos presos por capoeira entre 1808 e 1850 eram escravos, e 71\% eram africanos (84\% deles, da África central). A presença de crioulos já nesse período, afirma Soares (p.71), reforça a tese de que a capoeira é fruto da combinação de diversas tradições africanas com invenções culturais crioulas.

Mais do que um jogo de combate, a prática da capoeira tornou-se elemento importante na formação de identidades e no estreitamento de laços étnicos da população escrava, principalmente na primeira metade do século XIX. Também exerceu tal papel, com crescente conotação política na segunda metade do século, quando alargou sua composição social, atingindo um número maior de negros livres, e também abrangendo indivíduos de outros tons de pele e outras nacionalidades, diferentes de crioulos e africanos (SOARES, 1993).

Entretanto, sustentar tal afirmativa não deve nos fazer perder de vista a capoeira como importante espaço de sociabilidade para pretos e pardos, fossem escravos ou livres, malungos ou escravos de viajantes, como observa Soares. $E$ essa característica se acentuou na segunda metade do XIX (p. 47), quando as maltas de capoeira atingiram sua força máxima no cenário carioca, politizando-se de forma até então inédita.

Esse processo se dá ao mesmo tempo em que o carnaval se torna a principal festa carioca, suplantando mesmo as festas religiosas. Era momento propício para esconder-se sob diabos em meio à multidão e "ocultar-se dos agentes da ordem, realizar com maior segurança as vinganças pessoais (...) e exprimir rivalidades" (SOARES, 2002, p. 303).

Não é por acaso a recorrência de notícias sobre a prisão de capoeiras no carnaval: os números beiram a centena ano a ano. Quando os jornais explicitam o tipo de fantasia, a que aparece associada aos capoeiras é a de diabinho. "Punhalada - um grupo de capoeiras disfarçados de diabinhos, agrediu anteontem no beco das Cancelas o preto Justino, escravo do Comendador Luiz José da Silva Guimarães, o qual foi gravemente ferido por um deles com uma punhalada no peito" (JORNAL DO COMMERCIO, 7.2.1883).

Tal característica das páginas dos jornais nos dias de carnaval reforça a tentativa de associar a imagem dos capoeiras com o diabo e, mais do que isso, atrelar a fantasia de diabinho à prática da capoeiragem, da violência, do crime e da desordem. 


\section{LIBERDADE DIABÓLICA}

A figura do diabo nas ruas da Corte ameaçava não apenas o carnaval civilizado sonhado por muitos jornalistas, mas também projetos de nação e cidadania que estavam em disputa. A associação dos diabos com os capoeiras, violência, crimes e perigo, e com sua aproximação com sujeitos reconhecidos como crioulos, pardos e pretos traz consigo o temor das elites políticas e intelectuais em relação ao rumo da nação após a abolição que se aproximava: o diabinho representado no folião destemido e abusado que, com humor e doses de violência, expressava seu desejo de participar da nação ativamente, influenciando em seus rumos não apenas como plateia do carnaval civilizado e ordenado representado pelas grandes sociedades carnavalescas.

Considero, portanto, o diabo personagem que - na prática e simbolicamente - potencializava o temor dos senhores "de ver riscada da gramática das relações sociais, junto com a palavra escravo, a condição social dos homens brancos, construídas por séculos com tanto esmero", parafraseando Wlamyra Albuquerque (2009).

Ela é a única fantasia explicitamente nominada nos jornais quando relatam um crime. Grupos inteiros agindo pelas ruas, desordens e confusões que na perspectiva dos jornalistas ameaçavam seriamente a implementação de uma festa civilizada, digna de uma nação civilizada.

Conforme avançam os anos, como produto da constante associação de mascarados e crimes, perigo e violência, mais medidas repressivas contra o entrudo e as práticas do carnaval das ruas são exigidas e anunciadas pelos jornais. Em 1887, a Gazeta de Notícias afirma que o número de diabinhos no carnaval é menor do que nos anos anteriores. Atribui tal fato à proibição de diabinhos maiores de 15 anos pelo chefe de polícia e o recolhimento de mais de 400 pessoas ao xadrez, "por conveniências de saúde" e para "livrá-las de constipações". "Pelo que a polícia lavra mais um tanto", conclui a Gazeta de Notícias (22.2.1887).

Representantes das vertentes abolicionistas presentes nos jornais e no parlamento não viam contradição em defender o fim da escravidão e pregar o combate às práticas culturais dessa mesma população e de seus descendentes.

Como nos mostra Ângelo Agostini (Figura 3) muitas vezes o negro nem precisava de máscara para ser associado ao diabo nos dias do carnaval. À esquerda um velho representando o antigo carnaval. Do lado direito, um jovem mascarado dá vida ao Carnaval de 1886. Ambos seguram um arco com a data de abertura do reinado de Momo, 7 de março (o MEQUeTREFE, n. 401, ano 12, 1886). 


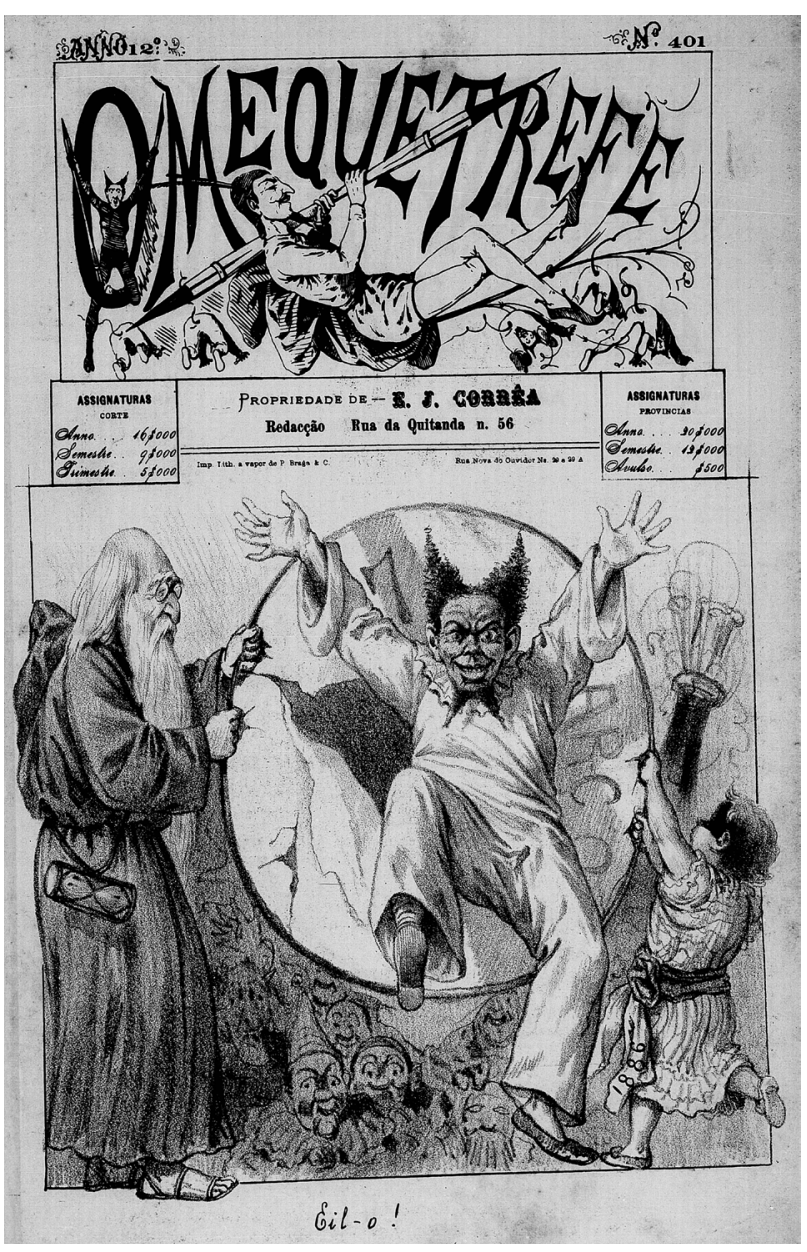

Figura 3: Ângelo

Agostini. O Meque-

trefe, n. 401, ano 12,

1886

Abruptamente, rompe o pano um negro fantasiado que enverga chifres, não de uma máscara vermelha, mas sim feitos com seus próprios cabelos carapinhados. Simbolicamente, Agostini nos revela, primeiramente, a imagem que muitos companheiros das letras e também autoridades faziam do carnaval das ruas: um negro com chifres "naturais", com olhar vidrado e diabólico.

Segundo Lilia Schwarcz (1987), é com o clímax da abolição da escravidão que o problema da raça ganha espaço entre as discussões da elite brasileira. "Assim, com o advento da igualdade formal, com a passagem do escravo a cidadão, parecem surgir novas concepções e estereótipos" (p. 36-37). A autora afirma que o auge do pensamento racial no Brasil ocorreria entre as décadas de 1890 e 1920, período em que a noção de superioridade branca seria legitimada cientificamente. 
A charge de 1886 reforça imagens estereotipadas e preconceituosas que ganhavam força no contexto da abolição da escravidão entre intelectuais e pensadores brasileiros. Entretanto, não devemos afirmar que tais concepções fossem hegemônicas ou que não houvesse espaço para outras análises da ação da população negra.

Podemos (e devemos) também analisar a imagem por outro viés: o folião negro participando ativamente da passagem do antigo para o novo carnaval (civilizado e moderno). Percebemos que a festa era disputada por inúmeros grupos sociais e que a população de cor ansiava por espaços de autonomia e participação nesse evento que anualmente era alardeado nos mais variados meios como o tempo da liberdade. Sua atuação na festa Ihes parecia elemento central na experiência de liberdade que anualmente ganhava força não apenas para os escravizados, mas também para a população negra livre.

Ora, se o carnaval foi alçado à condição de festa civilizatória por membros das elites intelectuais e políticas do Brasil, também foi eleito como espaço de dramatização de desejos de participação na sociedade que se pretendia construir pela população negra. Foi evento que, ao mesmo tempo em que servia para reforçar tradições e práticas culturais da população negra, servia como espaço de luta e transformação das relações sociais.

Muitas práticas sociais de matriz africana encontraram espaço de manutenção na festa de Momo, pois até as autoridades consideravam esses dias mais permissivos. A transposição de folias de reis, ranchos, cucumbis, e mesmo de diabos e outras fantasias para os dias de carnaval não ocorreu sem conflitos e rupturas, muito pelo contrário: para manter suas tradições culturais foi preciso transformá-las de acordo com as novas tensões e discussões presentes na década de 1880. Interpretaram com suas concepções de liberdade o carnaval e através dele politizaram sua experiência.

Ser um diabinho negro que sobe em um carro de ideias a favor do abolicionismo e dança diante da multidão, composta pelas mais ilustres famílias da Rua do Ouvidor, pelos jornalistas dos periódicos mais importantes do Império, pelas autoridades policiais, além de todos os seus pares do "Zé-Povinho", ganha novos sentidos - diretamente relacionados ao caráter do processo abolicionista da Corte, com o avanço da década de 1880.

Esses novos sentidos podem ser medidos através de dois elementos. Primeiro, pela constante perseguição aos máscaras, sobretudo aos diabos e sua associação a uma imagem de crime e perigo, presentes nos jornais e na crescente repressão policial aos pretos, pardos e fulas. Em segundo lugar, temos a crescente ousadia desses fantasiados, principalmente aqueles membros de maltas 
de capoeira que atuarão no carnaval com grande afinco. Conforme mostrou Soares (1993), confrontos entre "Nagôas e Guaiamus" tornar-se-ão frequentes nos anos finais da escravidão, assim como sua atuação, mais regular nos conflitos entre abolicionistas e defensores do escravismo.

O crescimento do sentimento abolicionista é sensível nos dias do carnaval, em que os carros das grandes sociedades carnavalescas que representavam a Liberdade eram sempre os mais aplaudidos dos préstitos; em que o povo delirava ao ver ex-escravos sendo alforriados. Os próprios ex-escravos tomam parte na propagação desse movimento. No dia 18 de fevereiro de 1888, a Revista llustrada narra da seguinte forma os préstitos carnavalescos das grandes sociedades:

Congresso dos Fenianos (...) logo após vinha um carro simbolizando a questão abolicionista, e que o público recebia com palmas e bravos, testemunhando, assim, a sua simpatia pela grandiosa ideia ali exibida. Representava ele um grupo de escravos, maltratados pelo senhor, que, julgando-se seguro, entregava-se a todas as sanhas. Quando, porém, menos pensava surgia a figura de um grande parlamentar abolicionista e aplicava-lhe um ruidoso pontapé, no lugar em que as costas... mudam de nome.

O povo ria e aplaudia a mais não poder!

Acompanhavam este carro 17 pretos montados em burricos e fazendo discursos às massas, sobre a escravidão e almejada liberdade $(. .$.

Fechava o grandioso préstito dos Democráticos, uma apologia à abolição, que há de trazer o progresso e a grandeza a este país desorganizado. Os bravos e as palmas com que foi acolhida esta belíssima apoteose, não tinham conta. Pode-se dizer que ela atravessava a cidade, em meio de uma constante ovação (...)

Os projetos abolicionistas paternalistas e reformistas das grandes sociedades entravam em contato com outras formas de conceber a liberdade. Nas ruas a "pureza" das ideias das elites políticas e intelectuais era perdida, pois escravos, libertos e negros livres pobres tentavam fazer valer seu direito de festejar e celebrar a liberdade de sua maneira. Esses confrontos geraram inúmeros desconfortos para intelectuais e políticos favoráveis à abolição, mas temerosos da nova condição de liberdade desses sujeitos.

Um dos caminhos mais utilizados pela população de cor da cidade do Rio de Janeiro para expressar suas críticas e mostrar sua concepção de liberdade e diversão foi o carnaval, centrada na autonomia para ocupar espaços da festa não apenas como plateia de desfiles, mas como ator principal nesse espetáculo. Ou seja, colocar em prática sua cidadania. Podemos entender essa nova pos- 
tura como expressão de uma cultura política que se construiu e fortaleceu nos anos finais da escravidão e tinha como elemento central a noção de liberdade. Essa noção dialogou constantemente com as redes sociais mais amplas de defesa da abolição, cada vez mais populares e difundidas na segunda metade da década de 1880.

O carnaval representou evento anual que permitia a essa população experimentar o avanço das ideias abolicionistas e de suas aspirações individuais à participação. Os diabinhos estão no centro desse movimento, pois pautaram formas de agir e também justificaram caminhos de repressão. Eles nos ajudam a entender, sobretudo, a dimensão individual dessa possibilidade.

Quando diabinhos tomam de assalto as ruas da capital imperial, através de humor, dança, doses de violência e ousadia, associados a capoeiras e muitas vezes caracterizados como jovens negros, pardos e crioulos, sua ação ganha novos sentidos na década de 1880. Demonstram, a partir de seus pontos de vista, que não vão abrir mão de sua autonomia festiva e liberdade carnavalesca, apesar da constante perseguição e repressão a suas práticas. Esse exemplo de ampliação da ousadia individual da população de cor esteve imbricado aos avanços abolicionistas à medida que tal discussão ganhava as ruas. Diabinhos, mesmo que de forma não explícita ou consciente, experimentavam os limites da tão aventada liberdade, seja a liberdade carnavalesca, defendida pelos jornalistas e préstitos das grandes sociedades, ou a Liberdade (com letra maiúscula), único caminho para a modernização do Brasil, como defendiam os principais grupos abolicionistas.

\section{REFERÊNCIAS BIBLIOGRÁFICAS}

ALBUQUERQUE, Wlamyra. O jogo da dissimulação: abolição e cidadania negra no Brasil. São Paulo: Companhia das Letras, 2009.

ANDRADE, Mario. Dicionário musical brasileiro. Belo Horizonte/São Paulo: Itatiaia/USP, 1989.

ANDREWS, C. C. Brazil: its condition and prospects. New York: D. Appleton \& Co., 1887.

ASSUNÇÃO, Matthias Röhrig. Capoeira: The History of an Afro-Brazilian Martial Art. London/New York: Routledge Taylor/Francis Group, 2005.

AZEVEDO, Célia Maria Marinho. Onda negra, medo branco - o negro no imaginário das elites (século XIX). Rio de Janeiro: Paz e Terra, 1987.

CASCUDO, Luís da Câmara. Dicionário do folclore brasileiro. Rio de Janeiro: INL (1954), 3. ed., 1972.

CHALHOUB, Sidney. Cidade febril: cortiços e epidemias na Corte imperial. São Paulo: Companhia das Letras, 1996. 
COARACY, Vivaldo. Memórias da cidade do Rio de Janeiro. Rio de Janeiro: José Olympio, 1965.

CUNHA, Maria Clementina Pereira. Ecos da folia: uma história social do carnaval carioca entre 1880 e 1920. São Paulo: Companhia das Letras, 2001.

EDMUNDO, Luiz. O Rio de Janeiro do meu tempo. Rio de Janeiro: Imprensa Nacional, 1938. $3 \mathrm{v}$.

MACHADO, Maria Helena P. T. O plano e o pânico. Os movimentos sociais na década da abolição. Rio de Janeiro/São Paulo: Editora UFRJ/Edusp, 1994.

MATTOS, Hebe. Escravidão e cidadania no Brasil monárquico. Rio de Janeiro: Jorge Zahar, 2004.

MORAES FILHO, Mello. Festas e tradições populares no Brasil. Belo Horizonte: Itatiaia, 1979.

NEPOMUCENO, Eric Brasil. Carnavais da abolição: diabos e cucumbis no Rio de Janeiro (1879-1888). Dissertação de Mestrado - Universidade Federal Fluminense, Instituto de Ciências Humanas e Filosofia, Departamento de História. Niterói, 2011.

QUEIROZ, Maria Isaura Pereira de. Carnaval brasileiro: o vivido e o mito. São Paulo: Brasiliense, 1992.

SCHWARCZ, Lília. Retrato em branco e negro. São Paulo: Companhia das Letras, 1987.

SILVA, Antonio de Moraes. Dicionário da língua portuguesa. Rio de Janeiro: A. Litho-typographia Fluminense, fac símile da segunda edição (1813), 1922.

SOARES, Carlos Eugênio Líbano. Festa e violência: os capoeiras e as festas populares na Corte do Rio de Janeiro (1809-1890). In Maria Clementina P Cunha (org.). Carnavais e outras f(r)estas. Ensaios de história social da cultura. Campinas: Unicamp, 2002.

"A negregada instiuição" Os capoeiras no Rio de Janeiro, 1850-1890. Dissertação de mestrado - Universidade Estadual de Campinas, Instituto de Filosofia e Ciências Humanas, Departamento de História. Campinas, 1993.

\section{NOTAS}

1 Este artigo é uma adaptação do capítulo "Diabos Encarnados", parte de minha dissertação de mestrado desenvolvida no âmbito do Programa de PósGraduação em História Social da Universidade Federal Fluminense, com bolsa concedida pelo CNPq, e defendida em 2011, cujo título é Carnavais da abolição: diabos e cucumbis no Rio de Janeiro (1879-1888). Estas conclusões foram apresentadas anteriormente no I Seminário Caminhos da Abolição e do pósAbolição (PPGH/UFF), 2010.

2 A palavra fula nesse contexto aparece nos jornais caracterizando também a população negra. Encontramos a utilização da expressão "preto fula", "preta fula" nos jornais coevos. Essa palavra tem origem na costa ocidental da África. 
Segundo Alberto da Costa e Silva, os fula (ou fulani) eram um povo da região do rio Senegal e da bacia do rio Gâmbia, atualmente a região composta por países como Senegal, Gâmbia e Guiné. Essa parte da costa ocidental da África foi uma das primeiras a estabelecer comércio de ouro e escravos com os ávidos portugueses, ainda no século XV. Não pretendo, obviamente, afirmar que os sentidos da palavra fula se mantiveram os mesmos desde a chegada das caravelas portuguesas na Senegâmbia até as prisões de carnavalescos na década de 1880 no Rio de Janeiro. Contudo, é muito importante ressaltarmos que as palavras também têm história, logo, não é por acaso a utilização do termo fula para designar indivíduos não brancos três séculos depois dos primeiros escravizados desembarcarem em terras brasileiras.

3 Não encontrei os registros de Luiz Ezequiel Pinheiro, Francisco Alves de Souza, José Pereira Garcia e Alfredo de Tal nos Livros de Matrícula da Casa de Detenção.

4 Ver Silva, 1922; Andrade, 1989; Cascudo, 1972; Coaracy, 1965; Edmundo, 1938; Moraes Filho, 1979.

5 A expressão "população de cor" era usada no período estudado para designar pretos, pardos e fulas, e muitas vezes englobava também seus descendentes.

6 A noção de classes perigosas ganha espaço entre autoridades e membros das elites cariocas no último quartel do século XIX, respondendo às necessidades de controle e manutenção da ordem em meio à crise do sistema escravista. Segundo Chalhoub (1996, p. 21-24), a associação das classes pobres com a noção de classes perigosas e a consequente imagem de perigo e violência dialogavam com os debates sobre a questão da cidadania, do trabalho, da atuação do Estado e da polícia em relação à população negra que emergia da luta pela liberdade. O contexto histórico em que essas formulações foram produzidas "fez com que, desde o início, os negros se tornassem os suspeitos preferenciais" e representantes dessas "classes perigosas" (CHALHOUB, 1996, p. 21-24).

7 Ângelo Agostini e sua revista estavam diretamente alinhados ao modelo de carnaval e mesmo de abolicionismo pregado pelas grandes sociedades.

8 Não pretendo discutir aqui as possíveis origens da capoeira e a sua "invenção" ainda no continente africano. Mas é importante ressaltar que entendo a capoeira fazendo parte de um contexto atlântico, não sendo nem apenas brasileira nem africana: ela é um desenvolvimento crioulo, um produto do processo de crioulização das culturas afro-americanas. Nas palavras de Matthias Assunção (2005, p.31), “Crioulização - no sentido amplo que estou usando aqui - implica tanto processos de fusão quanto de segmentação, bem como a realocação de determinadas práticas em novos contextos e manifestações mais abran- 
gentes. Essa discussão nos ajudará a acessar as características crioulas da capoeira e considerar o que manteve relações de complementariedade com outras práticas culturais" (tradução minha).

Eric Brasil Nepomuceno é mestre e doutorando do PPGH/UFF. Sua dissertação de mestrado, intitulada Carnavais da abolição: diabos e cucumbis no Rio de Janeiro (1879-1888), conquistou o primeiro lugar no Concurso de Monografias Sílvio Romero 2011 promovido pelo Centro Nacional de Folclore e Cultura Popular/Iphan.

Recebido em: 19/06/2012

Aceito em: 18/07/2012 